\title{
Delimiting Marine Areas: Ecosystem Approach(es?) in EU Marine Management
}

\author{
Aron Westholm
}

\section{$1 \quad$ Background}

Marine management is a question of delimitations. The sea is a large ecosystem, which, for functional governance, needs to be broken down into smaller, more manageable, units. A central issue for such governance is: what are the appropriate geographic delimitations in terms of ecosystem functionality? A related and equally important question is: what management level within the administrative system is best suited for such governance? These issues are important to discuss as they relate to how a legal regime for the sustainable management of marine ecosystems can be designed. This chapter utilises a theoretical framework grounded in legal geography to examine the way in which choices of management levels and geographical scales affect the functional application of the ecosystem approach. This examination is based on an analysis of management levels and geographic delimitations applied in the Swedish transposition of three different EU directives, which are themselves examined in order to ascertain whether it is possible to claim that there is a coherent definition of an ecosystem approach ${ }^{1}$ within EU marine legislation.

Over the last decade, the ecosystem approach has become a common tool in environmental governance. Various definitions and interpretations are used and there is probably no single, functional, understanding of the concept across different legal systems. However, the 'Malawi principles', adopted by the Parties to the Convention on Biological Diversity (СВD), articulate 12 principles for a coherent application of the ecosystem approach that have been internationally agreed upon. ${ }^{2}$ Two of these principles are of importance for the purposes of this chapter: Principle No 2, which stipulates that ' $[\mathrm{M}]$ anagement should be decentralised to the lowest appropriate level'; and, Principle

1 Within the directives this approach is labeled 'ecosystem-based approach'. However, for the sake of consistency in this chapter I will use the term 'ecosystem approach' also when referencing the directives.

2 UNEP/CBD/COP/5/23, Decision V/6 Ecosystem Approach, (2000).

(C) ARON WESTHOLM, 2019 | DOI:10.1163/9789004389984_005

This is an open access chapter distributed under the terms of the prevailing CC-BY-NC License at the time of publication. 
No 7, which stipulates that '[T]he ecosystem approach should be undertaken at the appropriate spatial and temporal scales'. These principles both have geographical implications: Principle No 7 as it relates to the spatial delimitations of ecosystems; and Principle No 2 as the competence, or jurisdiction, of each management level is restricted administratively, as well as geographically, in relation to other management levels.

Although concisely formulated, these two principles give rise to a crucial question: What constitutes 'appropriate' in the context of spatial and temporal scales of ecosystems? The answer to this question may be illusive given that ecosystems are complex and intertwined, land-based activities have great effects on marine ecosystems, and administrative boundaries are unlikely ever to correspond precisely to those of a natural ecosystem. Nevertheless, choices of scale and management level need to be made.

From an EU perspective, directives aimed at governing marine ecosystems through the application of an ecosystem approach, need to be specific as to what and where that ecosystem is. Ideally, the appropriate level and scale will be the same throughout union legal acts, as long as those acts use the same explicit approach and cover the same geographic area. This, in itself, would provide some substance to the term 'appropriate'. However, when looking at the three main legislative acts pertaining to the marine environment, it is clear that there is no coherent definition of what constitutes the 'appropriate' scale or management level.

For the purposes of this chapter, coherence is understood as being 'about the substantive harmony of law. It is a quality of legal principles rather than rules. $^{34}$ This broad understanding makes it a useful concept with which to explore the ecosystem approach, as it can relate to the application of the approach, rather than to how the approach is expressed in the legal acts. While there are many levels to coherence, for example coherence within an entire legal system or within smaller fragments of it. In the analysis section of this chapter I use the concept as referring to coherence within a certain field of EU law, to wit, the field of marine governance.

In examining the question of coherence, I use the emerging concept of legal geography. This will help to provide an analytical framework for an examination of the implications that choices of management level and ecosystem

3 Kaarlo Tuori, Ratio and voluntas: the tension between reason and will in law (Ashgate 2011) 153.

4 This concept has been debated, see e.g.: Aulis Aarnio, On coherence theory of law (Lund: Juristförl.: Akademibokh. distributör 1998). Tuori speaks of a type of local coherence, where it is only within specific fields of law that it can be possible to reach any kind of coherence. Tuori (n 3 ) 172. 
scale may have for the functional application of the ecosystem approach. In the next section, legal geography is presented as the theoretical framework through which the relevant directives are analysed. The following sections discuss how multiple management levels and ecosystem scales exist at the same time within the EU legal system, creating a legal plurality of sorts within EU management of marine areas. ${ }^{5}$

Much has been written about the ecosystem approach. However, little attention has been paid to how the legal system, when paired with the geographic context in which the approach is applied, administratively creates ecosystems. In essence, little attention has been paid to the issue of the 'legal geography' of the ecosystem approach. Here, 'legal geography' is used as a relatively broad theoretical approach to analysing the law. A basic concern of this approach is to explore and explain how law and space are intertwined and how they constitute and re-constitute each other. Law is located in space, just as law also renders legal significance to physical and social spaces. ${ }^{6}$ In other words, law both defines and is defined by space. This concept of space is somewhat elusive. ${ }^{7}$ Here, however, it is referred to in a more specific term, 'legal space', which is understood as referring to a geographic area delimited through law. Thus, for present purposes, the primary focus of this chapter is directed to the consequences that different regulatory choices of spatiality may have for the application of an ecosystem approach. The spaces studied here are policy-based

5 Legal plurality in a spatial context is discussed inter alia by Franz von Benda-Beckmann and Keebet von Benda-Beckmann, 'Places That Come and Go: A Legal Anthropological Perspective on the Temporalities of Space in Plural Legal Orders' in Irus Braverman and others (eds), The expanding spaces of law: a timely legal geography (Stanford, California: Stanford Law Books 2014) $30-53$. The use in this text is somewhat altered from their definition since this chapter is concerned with spatial legal plurality within a particular legal system, not between systems.

6 See e.g. Irus Braverman and others, 'Expanding the Spaces of Law' in Irus Braverman and others (eds), The expanding spaces of law: a timely legal geography (Stanford, California: Stanford Law Books 2014) 1.

7 See e.g. Henri Lefebvre, The production of space (Oxford: Basil Blackwell 1991); Doreen B. Massey, For space (London: SAGE 2005). For more legal discussions on the concept see Mariana Valverde, “Time Thickens, Takes on Flesh": Spatiotemporal Dynamics in Law' in Irus Braverman and others (eds), The expanding spaces of law: a timely legal geography (Stanford, California: Stanford Law Books 2014) and David Delaney, The spatial, the legal and the pragmatics of world-making: nomospheric investigations (Routledge 2010). 
delimitations of nature, and questions are asked as to how these differ within a legal system and create overlapping legal spaces with different management structures.

However, space is not the only relevant aspect. As Osofsky notes, geographic understandings of scale can assist when evaluating whether, and if so in what manner, the jurisdictional scope of a legal entity should be co-extensive with that of the natural phenomenon (in this case a marine ecosystem) it aims to sustain. ${ }^{8}$ Thus, while not as widely discussed in the literature as space, the social and natural significance of choices of scale should not be underestimated. Neither should scale be seen as something fixed; differentiation of scales is a social practice and, when seen as such, it is possible to highlight, and problematize, different choices of scale. ${ }^{9}$ This requires discussions of scale, of whether there is such a thing as appropriate scale, and of how different choices of scale affect implementation. ${ }^{10}$ This is particularly relevant because, as De Sousa Santos notes, choices of scale and perspective are normative. Thus, choosing an appropriate geographical scale of governance, or an appropriate level of management will ultimately affect how the legislation is used.11

The choice of scale, the 'what'12 to be governed, entails sacrifices, either in detail, or in how much of the entity to be governed is captured. A local scale will be high in resolution and detail. A national, or international scale, on the other hand, will represent lower resolution, ${ }^{13}$ providing a general overview, but entailing a loss in detail. This choice of scale issue is not merely a legal one; it is equally true in ecological sciences, where ecosystems need to be broken down into smaller units to be studied. Research has shown that patterns that can be found on one spatial scale, may be invisible at another. ${ }^{14}$ The choice of scale is

8 Hari Osofsky, Scales of law: Rethinking climate change governance (ProQuest Dissertations Publishing 2013) 31.

9 See e.g. Neil Smith, 'Geography, Difference and Politics of Scale' in Joe Doherty, Elspeth Graham and Mo Malek (eds), Postmodernism and the social sciences (Basingstoke: Macmillan 1992), 57-79.

10 Not much focus has been directed at scale within the field of legal geography. For a discussion on this see Osofsky (n 8).

11 Boaventura De Sousa Santos, Law: A Map of Misreading - Toward a Postmodern Conception of Law (1987).

12 This 'what', is of course ecosystems, but it also encompasses the questions of where these ecosystems are situated and how they are delimited.

13 De Sousa Santos uses the terms large/small scale. I have chosen to call this high/low resolution as I believe these are clearer terms.

14 Nathan Sayre, 'Ecological and geographical scale: parallels and potential for integration' 29 Progress in human geography $276,279$. 
thus important in the social, as well as in the natural, sciences. Its importance is accentuated in the inter-disciplinary work of environmental management.

The choice of management level, i.e. 'who' does the governing, will entail choices of projection revealing what the limits of operations are. This projection will in turn affect how neighbouring areas are treated. An example of this would be choosing a national government agency as the appropriate management level. In De Sousa Santos' terms this would be a medium scale, and the projection would be national. The marine environment in neighbouring states would receive less attention than the national environment, but at the same time, local details may be lost due to prioritisation of national interests. ${ }^{15} \mathrm{I}$ refer to these choices of scale and level as choices of jurisdiction.

These choices of jurisdiction lead to a third, more tacit choice, namely that of 'how' management will be performed. This 'how' has previously been discussed in terms of choices between different applicable laws in particular cases. ${ }^{16}$ However, it is equally valid to discuss this 'how' question in terms of which administrative body is performing the management. Local governments, such as municipalities, are not likely to take the same approaches to resource management as regional, national or international authorities. Similarly, a ministry of finance will not have the same perspective as a ministry responsible for environmental protection. Based on this assumption, or hypothesis, of the importance of 'who' and 'what', I will discuss issues of fragmentation within EU marine policy in the concluding sections of this chapter.

The need for these choices flows from a number of circumstances. As a general matter, there may be pre-existing administrative structures and bodies that can be tasked with new assignments. For example, when transposing EU directives into national legislation, choices in ministries responsible for the implementation can be guided by the purposes of the directives. Such purposes are reflected in the legal basis for the directive. The Marine Strategy Framework Directive (MSFD), ${ }^{17}$ for example, has a clear environmental purpose and is thus adopted on the legal basis of environmental policy. However, for framework directives with less distinct purposes, and multiple legal bases, such as the Maritime Spatial Planning Directive (MSPD), ${ }^{18}$ in which extensive

\footnotetext{
15 De Sousa Santos (n 11), 278.

16 For a discussion relating to this, see Mariana Valverde, Jurisdiction and Scale: Legal 'Technicalities' as Resources for Theory (2009).

17 Directive 2008/56/EC of the European Parliament and of the Council of the 17 June 2008 establishing a framework for the community action in the field of marine environmental policy (Marine Strategy Framework Directive) [2008] OJ L 164/19.

18 Directive 2014/89/EU of the European Parliament and of the Council of 23 July 2016 establishing a framework for maritime spatial planning [2014] OJ L 257/135.
} 
discretion is given to the individual member states, the constitutional infrastructure of a national administrative system will usually set the limits for the possible choices in management. In Sweden, for example, the municipalities traditionally have the exclusive competence for, inter alia, land and water-use planning within their boundaries, the so-called 'planning monopoly'.19 This has important implications for the design of Sweden's marine spatial planning (MSP) legislation.

At the EU level, the differences in perspectives can be demonstrated by reference to the different Directorate Generals (DG). While DG environment ${ }^{20}$ has a clear mission to protect the environment, DG MARE ${ }^{21}$ has a more economic focus. This has been described as leading to institutional tensions within the EU arising from the fact that although the DGs are responsible for implementing different directives, these directives sometimes cover the same substantive area. ${ }^{22}$ Moreover, these tensions are not only due to differences in mission, but also to differences in how the DGs are organised internally; DG MARE is divided into geographic directorates, while DG environment is divided thematically. This leads to further challenges in coordination. ${ }^{23}$

The following section analyses the three EU directives pertaining to the management of the marine environment in order to examine the manner in which different choices of geographical scale and administrative management levels may affect the functional application of the ecosystem approach to marine environmental management in the EU. The Swedish transposition of the directives is used to highlight how the differences between directives lead to inconsistent ecosystem delimitations on the national level.

\section{Legal Delimitations of Marine Areas in the EU}

Any attempt to delimit ecosystems geographically highlights the difficulty of interpreting nature in a human context. We need to make sense of nature, but to manage it we also need to divide it into smaller, more manageable, units.

\footnotetext{
19 See Planning and Building Act (2010:900), ch. 1 art. 2.

20 Directorate General for the Environment.

21 Directorate General for Maritime Affairs and Fisheries.

22 Elizabeth De Santo, 'The Marine Strategy Framework Directive as a Catalyst for Maritime Spatial Planning: Internal Dimensions and Institutional Tensions' in Michael Gilek and Kristine Kern (eds), Governing Europe's marine environment: Europeanization of regional seas or regionalization of EU policies? (Farnham, Surrey: Ashgate 2015).

Ibid., 99 .
} 
The geographical space is transformed into a legal space, or multiple legal spaces, with all the implications that follow.

To illustrate how ecosystems can be legally defined, I will use three directives that cover EU marine waters: The Water Framework Directive (WFD); ${ }^{24}$ the MSFD; and the MSPD. The latter two both make explicit reference to the ecosystem approach. ${ }^{25}$ While the WFD does not include such a reference, it has been claimed in subsequent official documents from the EU that the ecosystem approach is consistent with that directive. ${ }^{26}$ Indeed, out of the three, the WFD is the directive with the most elaborate system for defining ecosystems.

The implementation of the WFD and the MSFD has been widely discussed by both natural and social scientists. This chapter, however, applies a hitherto unused perspective, choosing to explore their implementation in terms of choices of scale and level. Discussion of the more recent and understudied MSPD is added to the analysis. The Swedish marine management system(s) is used to exemplify how the different definitions of ecosystems contained in the directives can affect the subsequent national implementation. It also highlights issues of coherence in the understandings of appropriate scales and levels of management between the three directives.

\subsection{The Water Framework Directive (WFD)}

The aim of the WFD is to reach and maintain a good ecological status for surface and groundwater in the EU. ${ }^{27}$ This directive is mainly concerned with fresh water management. Although the territorial waters up to 12 nautical miles $(\mathrm{nm})$ from the baseline are included, ${ }^{28}$ the area landward of one $\mathrm{nm}$ from the baseline, defined as 'coastal waters', is the most interesting part of the directive for the purpose of this analysis. ${ }^{29}$

In annex XI to the directive, European waters are divided into fresh water ecoregions and marine ecoregions. Each member state has the responsibility to manage their waters through so-called river basin-management. In practice,

24 Directive 2000/6o/EC of the European Parliament and of the Council of the 23 October 2000 establishing a framework for Community action in the field of water policy [2000] OJ L $327 / 1$.

25 Ibid., Art 1.3, and 2014/89/EU, art. 5.1.

26 European Commission, EU Marine Strategy. The story behind the strategy (2006) 24.

$272000 / 60 /$ EC, art. 1.

28 Territorial waters are included only in regard to the achievement of good surface water chemical status and are not central to the directive, focus is on the coastal waters, see ibid., art. 2.1. 2000/6o/EC, art. 2.7. 
this entails identifying river basins within national jurisdiction. These are then to be divided into river basin districts with competent management authorities assigned to them. ${ }^{30}$ Within each river-basin district, the waters are characterised as either river, lake, transitional water, or coastal water. These sub-categories are further divided into types of water based on (for coastal waters), inter alia, ecoregion, salinity and mean depth. Through characterisation and typing, the river-basin districts are divided into smaller fragments, so-called 'water bodies'. ${ }^{31}$ In terms of the ecosystem approach principles discussed above, the appropriate management level chosen here is the river-basin authority, and the appropriate scale is that of water bodies.

According to the directive, the characterisation and typing of water bodies should not be arbitrary. Rather, water bodies are to be 'discrete and significant elements. ${ }^{32}$ Each water body should be identified on the basis of its discreteness and significance in the context of the directive's purposes, objectives and provisions. ${ }^{33}$ Water bodies are thus determined by biological factors. In addition, there are human considerations in play that affect this determination. One water body cannot be split between categories of surface water, nor can it be split into different types. In short, a water body needs to be assigned one specific water type. These water bodies must, however, also be meaningful. Here anthropogenic factors, such as pressures, protected areas, or other uses can be considered in the refinement of the water body identification. No minimum scale of identification is stipulated, but the implementation strategy mentions that there is a need to avoid unmanageable fragmentation. ${ }^{34}$

Coastal waters are supposed to be assigned to the river basin district that is most likely to influence their quality, particularly taking into account longterm influences of any contaminants. The boundaries between two adjacent types should be decided so as to avoid unnecessary splitting of the coastline. As the final step in defining water bodies, the common implementation strategy suggests using administrative boundaries. ${ }^{35}$ This indicates that the ecological factors alone are not sufficient to adjust the natural environment to human management conditions.

\footnotetext{
$3^{\circ} \quad$ Ibid., art. 3 .

31 Ibid. Annex II.

32 Ibid., art. 2.10.

33 Common Implementation Strategy for the Water Framework Directive (2000/6o/EC) Guidance Document No 2, 5 .

34 Ibid., 9 .

35 Common Implementation Strategy for the Water Framework Directive (2000/6o/EC) Guidance Document No 5, 23-24.
} 


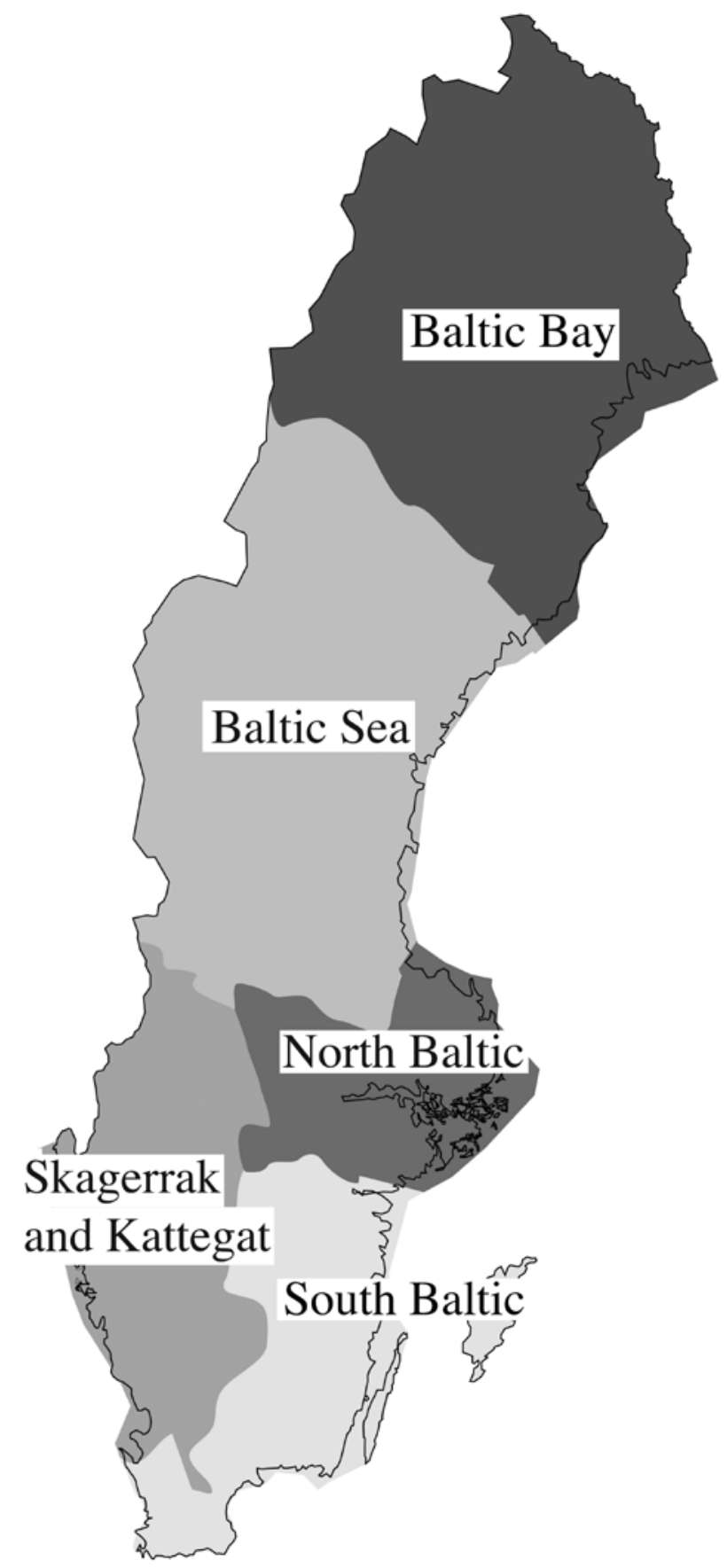

MAP 4.1 Catchment areas in Sweden as divided through the transpositioning of the WFD ILLUSTRATION CREATED BY HILLEVI DUUS 
The clear characterising and typology guidelines are intended to achieve coherent implementation throughout the EU. However, studies have shown that each member state develops its own typology. ${ }^{36}$ There are even inconsistencies within individual member states' typologies. When implementing the WFD in Sweden, for example, there have been differences in interpretation between different river basin authorities. ${ }^{37}$ In addition, while these typologies might be pedagogically suitable for public consumption, they still represent relatively crude delimitations of 'naturally continuous gradients across a wide range of ecosystem characteristics' ${ }^{38}$

In Sweden, the implementation of the WFD has led to the creation of five water authorities, each in charge of one of the identified river basin districts. These water authorities are responsible for characterising and defining water bodies. Although they are in some sense new administrative bodies, the water authorities are organizationally connected to pre-existing County Administrative Boards ( $\mathrm{CAB}){ }^{39}$ Thus, the geographical scale chosen for the implementation of the WFD is regional, as is the management level. The CABS are representatives of the central government, however, their mandate is on a regional (within Sweden) level. To visualise the above, Map 4.1 shows how the coastal waters of Sweden have been divided into five regions, or areas, within the frame of the WFD.

\subsection{The Marine Strategy Framework Directive (MSFD)}

The second directive considered is the MSFD. In the MSFD there is an explicit reference to the ecosystem approach and a requirement that it should be applied. ${ }^{40}$

When defining terminology in the MSFD, 'marine waters' are divided into waters seaward of the baseline and 'coastal waters' which are defined as in the WFD. The latter should only be covered under the MSFD insofar as their environmental status is not sufficiently addressed by the WFD. ${ }^{41}$ Within the frame of the directive, the marine waters of the EU are divided into four 'marine

36 Brian Moss, 'The Water Framework Directive: Total environment or political compromise?' 400 Science of The Total Environment 32, 35.

37 Gabriel Michanek, EU:s adaptiva vattenplanering och svenska miljörättsliga traditioner (2016) 356 .

38 Daniel Hering and others, "The European Water Framework Directive at the age of 10: A critical review of the achievements with recommendations for the future' 408 Science of the Total Environment 4007, 4012. 
regions' and eight 'sub-regions'. How these regions were identified is not entirely clear. The International Council for the Exploration of the Sea (ICES) produced a report defining the marine regions of Europe based on biological criteria. ${ }^{42}$ This was used as the basis for the MSFD division, although the end result was not entirely consistent with the proposal by ICES. It has been claimed that the introduction of marine regions in the MSFD was something new in EU marine law. ${ }^{43}$ Such claims fail to recognize that the WFD had already introduced marine eco-regions in 2000, although these were geographically somewhat different to those introduced by the MSFD. What was new in the MSFD, however, was an emphasis on regional cooperation.

To implement the directive, cooperation within the frame of Regional Seas Conventions ${ }^{44}$ is envisioned. How such cooperation is to be organized is not specified, and the directive itself does not provide any legal guidance to that end. ${ }^{45}$ The linkage to the Regional Seas Conventions has been explained as a mode of mending the inherent mismatch of scale between the ecosystem and institutional scales. ${ }^{46}$ However, this may be an overly optimistic interpretation given that the regional scales, in many cases, do not match those of ecosystems any more than the pan-European scale does. Moreover, the Regional Seas Conventions do not cover all sectors, as envisaged in the MSFD. For example, the Convention on the Protection of the Marine Environment of the NorthEast Atlantic (OSPAR Convention) covers the marine environment but issues regarding fisheries and shipping are exempted from its purview. ${ }^{47}$ From a Swedish perspective, coordination through the Regional Seas Conventions also means that implementation of the MSFD is coordinated through both the

42 ICES, 'Eco-regions advice to EC'.

43 Ronán Long, 'The Marine Strategy Framework Directive: A New European Approach to the Regulation of the Marine Environment, Marine Natural Resources and Marine Ecological Services' 29 Journal of Energy \& Natural Resources Law 1; Jan PM van Tatenhove, 'How to turn the tide: Developing legitimate marine governance arrangements at the level of the regional seas' 71 Ocean and Coastal Management 296.

44 It is not specified in the directive, however, the relevant conventions are: The ospaR Convention for the Protection of the Marine Environment of the North-East Atlantic (OSPAR), The Helsinki Convention on the Protection of the Marine Environment of the Baltic Sea Area (нецсом), The Barcelona Convention for the Protection of the Marine Environment and the Coastal Region of the Mediterranean (the Barcelona Convention), and The Bucharest Convention on the Protection of the Black Sea against Pollution (the Bucharest Convention).

45 Judith van Leeuwen and others, 'Implementing the Marine Strategy Framework Directive: A policy perspective on regulatory, institutional and stakeholder impediments to effective implementation' 50 Marine Policy 325, 327.

46 Ibid., 328.

47 Ibid., 328. 


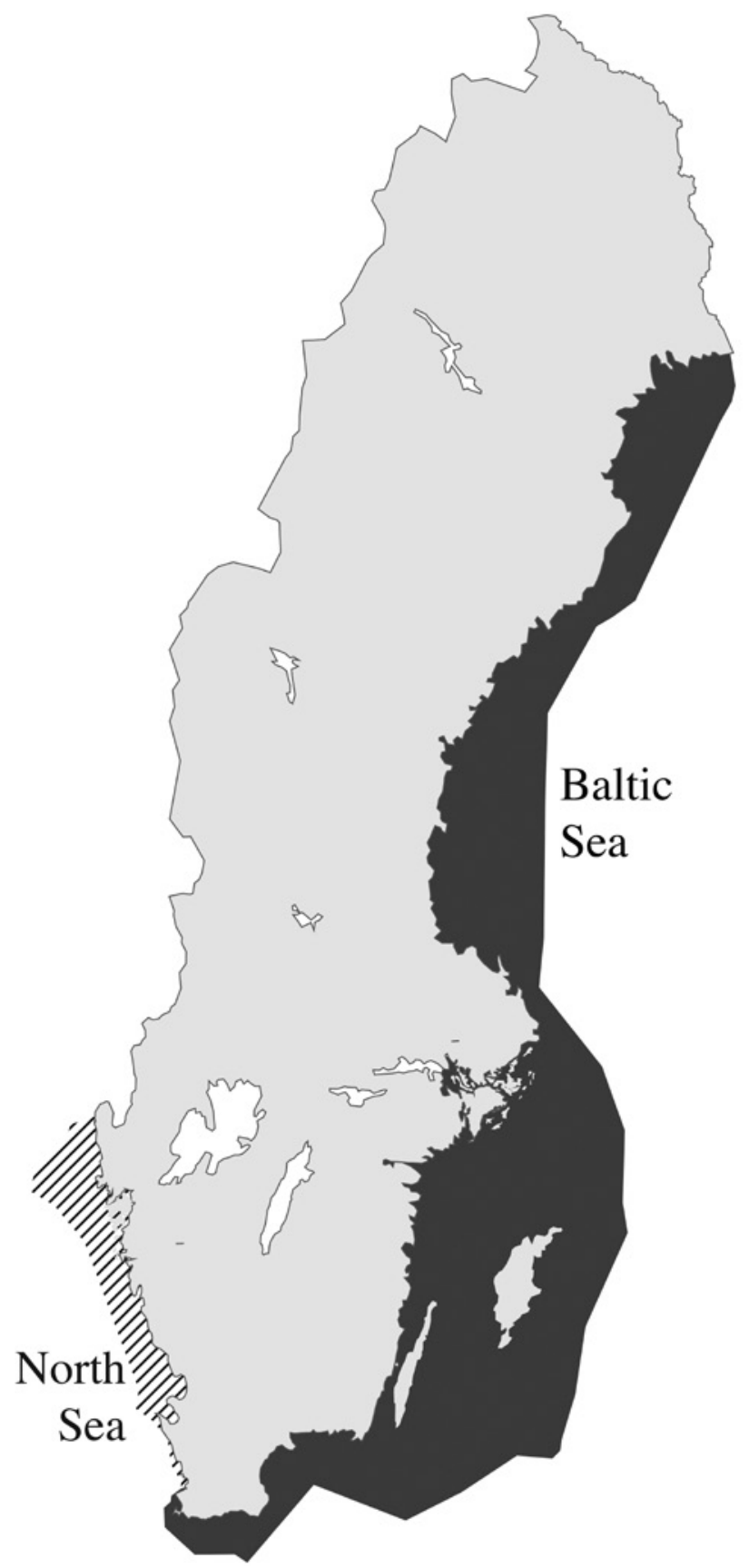

MAP 4.2 Swedish marine management areas as divided through the transpositioning of the MSFD

ILLUSTRATION CREATED BY HILLEVI DUUS 
OSPAR Convention and the Convention on the Protection of the Marine Environment of the Baltic Sea (Helsinki Convention) with the Swedish Agency for Marine and Water Management (SwAM) in charge of implementation. Thus, two different levels of management have been identified as appropriate, i.e. regional and national, and the regional level is divided between two Regional Seas Conventions that geographically overlap in the Kattegat.

At the national level, each member state has the opportunity to make further subdivisions of their marine waters at appropriate levels. ${ }^{48}$ Here it is up to the member state to decide, albeit with less guidance than in the WFD, what spatial delimitations seem appropriate. In the Swedish case, there have been no such further subdivisions. Swedish management is simply divided into two regions based on the sub-regions stipulated in the MSFD: The Baltic Sea and the North Sea.

The identification of ecosystems is not as elaborate in the MSFD as it is in the WFD. Yet, both seem to evidence the same basic idea as to how such identification is performed. In both cases this is to be based on biological criteria. The appropriate scale here is the marine region/sub-region, which entails a more centralised management level than that provided for in the WFD. Nevertheless, the two directives are apparently somewhat coordinated in that the assessment areas in the MSFD coastal waters coincide with the coastal water types identified through the WFD.

In a Swedish context, SwAM, a national government agency, is the competent authority responsible for the implementation of the MSFD. The scale of the ecosystems being governed here is the entire Swedish part of the Baltic Sea and the entire Swedish part of Kattegat/Skagerrak (see Map 4.2).

\subsection{The MSP Directive (MSPD)}

Out of the three directives, the MSPD is the one that has the least developed system for identifying ecosystems. It references the MSFD by stating that it shall use the same definitions of marine regions and the same division between marine waters and coastal waters. It further states that the definition of coastal waters in the WFD is to be applied. ${ }^{49}$ However, the MSPD is not applicable to coastal waters or parts thereof falling under a member state's town and country planning. ${ }^{50}$ It is a framework directive, and in many senses less specific than the MSFD. This has led to different interpretations among member states when transposing the directive into national law. In Lithuania, for example,

$48 \quad 2008 / 56 /$ EC, art. 4.2.

$492014 / 89 / \mathrm{EU}$, arts 3.3 and 3.4 .

5o Ibid., art. 2.1. 
the government has extended centralized land planning to include all of the marine waters. ${ }^{51}$ In Germany, the regional coastal states (Länder) have retained the competence of planning the territorial sea ${ }^{52}$ while the national planning only covers the exclusive economic zone (EEZ). In Sweden, the municipalities have exclusive planning competence over coastal waters out to $1 \mathrm{~nm}$ beyond the baseline, while the planning in the remaining $11 \mathrm{~nm}$ of the territorial sea is shared between the national government and municipalities, and the former has exclusive competence regarding the EEz.

Cooperation on a regional level is envisaged in the MSPD as well as in the MSFD, and there are Regional Seas Conventions in place that could facilitate this. However, the administrative differences presented above could complicate such cooperation. ${ }^{53}$ This is particularly so given that closer scrutiny of the different MSP regulations around the Baltic Sea reveals that no country has transposed the directive in the same way as another. ${ }^{54}$

As with the MSFD, the MSPD is to be implemented through the application of an ecosystem approach. ${ }^{55}$ Although the basic idea is to balance the three pillars of sustainable development, it has been pointed out that the directive prioritizes economic activities over the other two pillars, environment and human security. ${ }^{56}$ In regard to management level and ecosystem scale, the MSPD places responsibility on the individual member states. These shall designate the competent authorities for the implementation of the directive. ${ }^{57}$ The same is true for the ecosystem scale, although the directive provides no direct guidance on this and the member states have chosen different scales as being the most appropriate. In Sweden, this has resulted in three plan areas, two for the Baltic Sea and one for Skagerrak/Kattegat, all of which are coordinated by SwAM. In addition, there are approximately 80 coastal municipalities, each responsible for planning in its own coastal waters. As of now, the plans have not been adopted, thus the plan areas are yet to be definitively decided. The plans are expected to be adopted in 2020/21 (See Map 4.3).

$5^{1} \quad$ European MSP Platform, 'Maritime Spatial Planning Information, Lithuania' (2016) $<$ www.msp-platform.eu/countries/lithuania > accessed 2017-03-22.

52 European MSP Platform, 'Maritime Spatial Planning Information, Germany' (2016) <www .msp-platform.eu/countries/germany> accessed 2017-03-22.

53 Stephen Jay and others, 'Transboundary dimensions of marine spatial planning: Fostering inter-jurisdictional relations and governance' 65 Marine Policy 85, 93.

54 See the "European MSP Platform", European MSP Platform, <www.msp-platform.eu/> accessed 2017-04-11.

$552014 / 89 / \mathrm{EU}$, art. 5.1.

$5^{6}$ Antonia Zervaki, 'The legalization of maritime spatial planning in the European Union and its implications for maritime governance' 30 Ocean Yearbook 52, 42. 


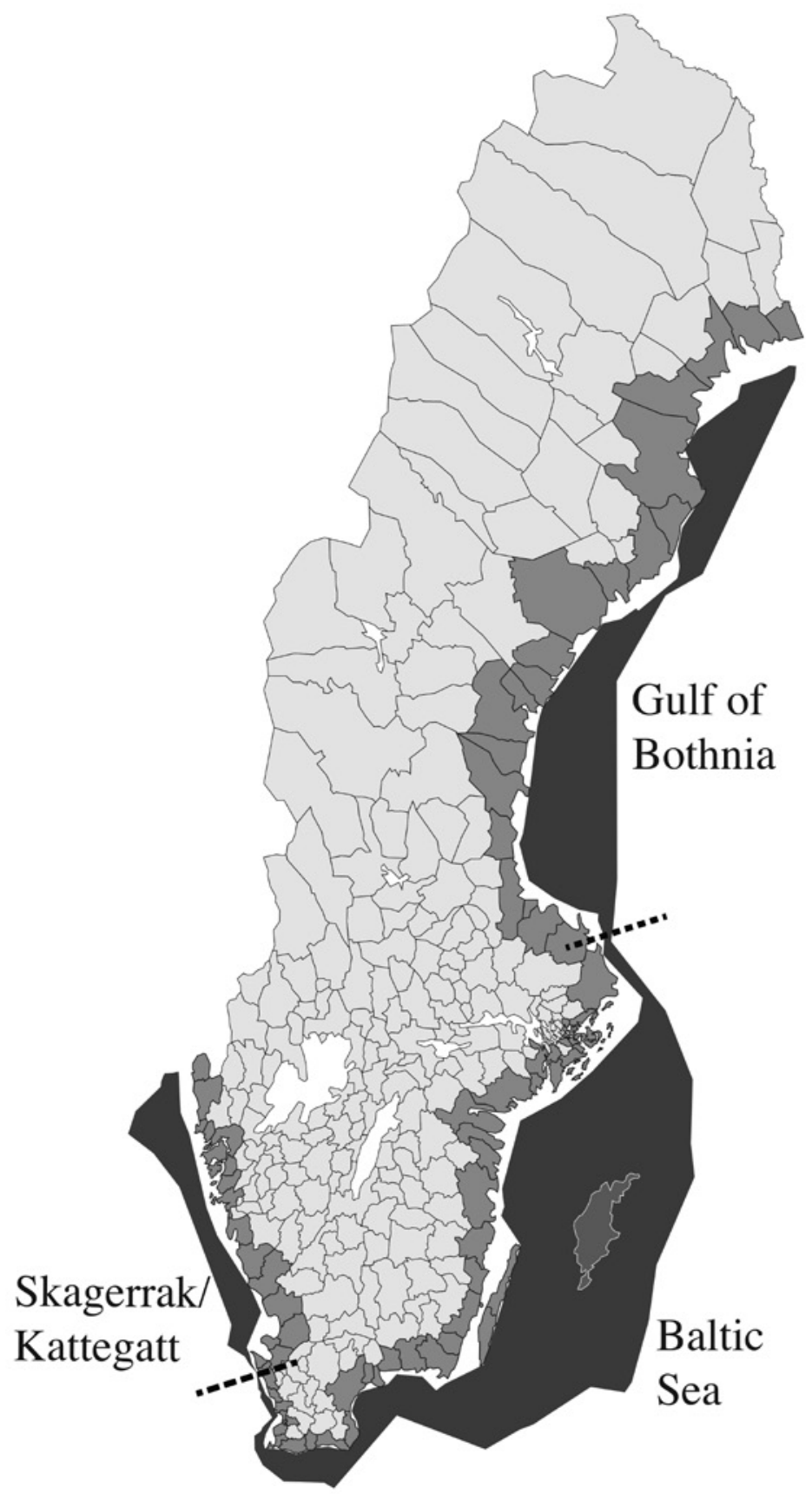

MAP 4.3 Map of the Swedish proposed national MSP areas and coastal municipalities

ILLUSTRATION CREATED BY HILLEVI DUUS 
Looking at how the three directives have been transposed in different member states, a picture emerges of great administrative challenges. There are obvious inconsistencies in what, from an EU perspective, should be regarded as the appropriate level/scale of ecosystem management. Some of the differences between the WFD and the MSFD have been investigated by Borja et al who make the point that the WFD has a 'deconstructing structural approach', while the MSFD has a more 'holistic, functional approach'.58 The idea behind the WFD, which was the creation of a new management structure, freed from administrative boundaries and instead focused on natural catchment areas, seems to have been deserted to some extent in the MSFD and completely abandoned in the MSPD.

The Swedish regimes for water and marine management serve as examples to highlight the discrepancies between the three directives. As shown above, the transposition of the directives has led to three different geographical and management divisions of the Swedish marine areas (see Map 4.4). As an extra layer to this division, there are the two Regional Seas Conventions, OSPAR and the Helsinki Convention, each with a different division of the areas. OSPAR also has functional differences compared to the EU directive, as both fisheries and shipping are beyond its scope. Furthermore, the EU Common Fisheries Policy sets the boundaries for action taken in regard to fisheries, which limits the competence of member states. ${ }^{59}$ Needless to say, it seems quite an administrative challenge to coordinate these different management levels and ecosystem scales.

The analysis of these three directives raises the question of what is actually meant by the ecosystem approach in an EU context. Since this chapter is concerned with ecosystem scale and management level, it is through that lens that the EU ecosystem approach is analysed. In the process leading up to the MSFD, ICES produced a document concerning the ecosystem approach to human activities in the European marine environment. One of the principles highlighted in that report states that 'the geographic span of management should reflect ecological characteristics and should enable management of the natural resources of both the marine and terrestrial components of the

$5^{8}$ Ángel Borja and others, 'Marine management - Towards an integrated implementation of the European Marine Strategy Framework and the Water Framework Directives' 60 Marine Pollution Bulletin 2175, 2176.

59 For a discussion on the relation between CFP and MSFD implementation in a Swedish context, see Anna Christiernsson, 'God miljöstatus och fiske - Hur effektiva är miljökvalitetsnormer?' 2015:2 Nordic Environmental Law Journal 93 (in Swedish). 

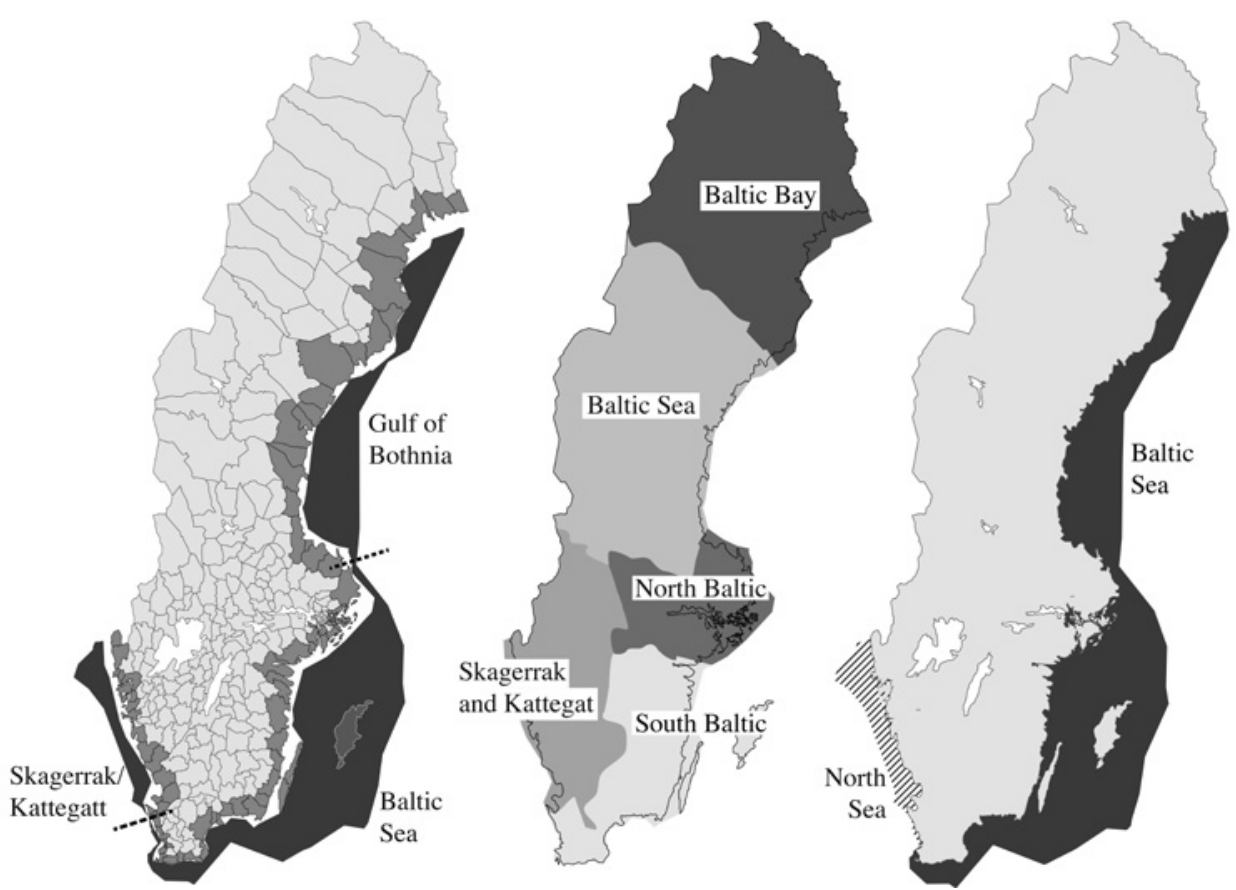

MAP 4.4 The Swedish marine areas as divided through the three directives ILLUSTRATION CREATED BY HILLEVI DUUS

coastal zone'60 This is the closest the document comes to discussing appropriate scale, even though it also references the Malawi principles. It is clear that in the WFD the ecosystem scale is based on scientific criteria (whether these criteria represent an unflawed mirror of those ecosystems is a discussion for another paper). The MSFD and the MSPD both take their starting point in the marine regions, which are based on a scientific division of the marine areas of Europe. But the MSPD is subsequently stripped of this scientific understanding, through the exclusion of coastal waters, an exclusion that has no scientific rationale, but is a construction based in politics. ${ }^{61}$

6o Jake Rice and others, 'ICES. Guidance in the Application of the Ecosystem Approach to Management of Human Activities in the European Marine Environment, ICES Cooperative Research Report, No. 273. 22', 2.

61 In an early version of the directive, as well as the impact assessment concerning the directive, the importance of including the coastal waters was stressed, however during the referral round it was clear such a construction was not favoured by the member states. See e.g. the referral statement from the Committee of the Regions: Committee of the Regions NAT-V-030, Opinion on proposed directive for maritime spatial planning and integrated coastal management (2013). 
Within these discrepancies lay two central problems. One problem is that the scientific delimitations of ecosystems are inconsistent between the directives. The Swedish example shows this with ample clarity. The second problem is that, as a result of, inter alia, the ecosystem delimitations, the competent authority responsible for implementation differs between the directives, an issue that runs a risk of leading to different rationales in management.

It would seem reasonable to assume an ambition for the three $\mathrm{EU}$ directives to be coherent as between and amongst each other. They originate from the same legislator and, at least in part, apply to the same geographic areas and interests; the coastal and marine environment. Although the directives use different scales and management levels, it could be expected that the understanding and application of the ecosystem approach would be coherent. This would be regarded as a type of local coherence, relating not to a field of law in general but to a certain branch within a field of law, i.e. marine governance. However, coherence may be affected by factors within the management levels as well, which brings us back to the concept of legal geography. How do these directives create legal spaces, and what implications do such legal spaces have for the coherent application of an ecosystem approach?

At first glance, it may seem as if the crucial issue for coherence between directives is the geographical scale chosen for ecosystem governance, i.e. 'the what' to be governed. Ecologists have argued for decades that if human responsibility does not match the scale of a natural phenomenon, unsustainable use is likely to occur. ${ }^{62}$ However, upon further reflection 'the who', i.e. at what administrative level the management takes place, emerges as an issue of equal significance. This is because 'the who' might come with different sets of logics or perspectives on management. As Valverde puts it when referring to the national level of governance: '[F] ocusing on sovereignty (who governs where) prevents us from asking interesting, novel questions about how we might govern and be governed'.63 This adds the third dimension discussed at the beginning of this chapter, the 'how', which refers to the tacit choice of rationale, or logic, that the choice of management level entails.

Referring to the Swedish setting, when the appropriate level of management for the coastal waters is identified as being the municipal level this leads to different management priorities than if the choice had fallen on the CABs or SwAM. ${ }^{64}$ In other words, when the municipal management level is chosen, a

\footnotetext{
62 Kai N. Lee, 'Greed, Scale Mismatch, and Learning' [Ecological Society of America] 3 Ecological Applications 560,561 .

63 Valverde (n 16), 145.

64 Ibid., 147.
} 
relatively high-resolution scale is applied, and the perspective of the management will be that of the municipality. Such a perspective may well entail different priorities in the management of marine resources than that of government agencies. The mission of a municipality is to take care of municipal matters. One might even argue that for a municipality to apply some kind of overall perspective on environmental issues would be against its mission if this would in some way be contrary to the interests of the municipality. This argument is based on the legal limitations of municipal action. In Sweden, a central principle for municipal operations is the so-called location principle', which (put in a simplified way) states that all municipal action must be of public interest and have a connection to the municipality and its inhabitants. ${ }^{65}$ Policies aimed at capturing complex environmental issues, where the municipal action can only affect a small part, may very well be seen as falling outside of such limitations.

This logic applies at all levels of management, as each level will have its own mission and perspectives, be they local, regional or national. Thus, choosing a management level, or jurisdiction, entails choosing a bundle of perspectives and logics that might not be immediately clear. ${ }^{66} \mathrm{In}$ this respect it is important to bear in mind that choices in management level also follow from pre-existing administrative arrangements in member states (see section 2).

Returning to the issue of coherence it would seem there is a need for coherence within the regulations pertaining to the marine environment as well as on a more substantive, principled level. Usually, the argument for coherence is foreseeability in adjudication. However, in the case at hand, the argument for coherence would not be foreseeability, but rather that the overall goal of reaching a sustainable use of the marine environment needs a coordinated and coherent management framework. When studying how the MSPD has been transposed into the national legal systems of EU member states, it seems clear that, if there is a coherent understanding of the ecosystem approach (which is not itself entirely clear), it is not communicated to the member states. The 'who' and the 'what' differs between the member states. In accordance with the theoretical assumptions made in the beginning of this paper, I argue that these factors will lead to differences in how the management is performed. Some states have placed responsibility for the planning efforts on national environmental agencies, others on the ministry of finance, while again others have placed it on regional or local authorities, each with their own management

65 Local Government Act (1991:90o), ch. 2 art. 1.

66 Richard T. Ford, 'Law's Territory (A History of Jurisdiction)' 97.4 Michigan Law Review 843 . 
rationale. ${ }^{67}$ All of this highlights incoherence in the management of the marine environment both at the EU and national levels. Furthermore, based on this analysis it is possible to seriously question whether there is one ecosystem approach in EU marine law, and if not, how should we make use of, and understand, the concept as it stands today.

\section{$5 \quad$ Conclusion}

This chapter has sought to examine whether it is possible to claim that there is a coherent definition of an ecosystem approach within EU marine legislation. As will be clear from the above, the answer to the central question posed appears to be 'no'. The three directives discussed in this chapter are all framework directives that set minimum requirements for member states in their management of the marine environment. There is no doubt that legal regimes that establish only minimum requirements in reality simply lead to setting a standard which few member states exceed. ${ }^{68}$ However, this chapter has further argued that there is an additional challenge with the system of framework directives. In short, when the different frameworks do not provide clear or consistent instructions as to the 'who' and 'what' of management, this leads to discrepancies in 'how' that management is performed. These discrepancies further create institutional challenges in the coordination of efforts, both between member states and internally, within individual member states. Such challenges and discrepancies are particularly unfortunate when governing complex and interconnected ecosystems, where coordinated efforts are essential.

$67 \quad$ For example, Finland has a system where the Ministry of Environment is the responsible ministry, but regional authorities have the responsibility to develop plans for both the territorial sea and the EEz. Denmark on the other hand, will adopt one plan for their entire marine area, and the responsible ministry is the Ministry of Business and Growth. For more information see European MSP Platform.

$68 \mathrm{JH}$ Jans and others, '“Gold plating” of European Environmental Measures?' 6 Journal for European Environmental \& Planning Law 417. 


\section{Table of Authorities}

\section{EU Directives}

Directive 2000/6o/EC of the European Parliament and of the Council of the 23 October 2000 establishing a framework for Community action in the field of water policy [2000] OJ L 327/1

Directive 2008/56/EC of the European Parliament and of the Council of the 17 June 2008 establishing a framework for the community action in the field of marine environmental policy (Marine Strategy Framework Directive) [2008] OJ L 164/19

Directive 2014/89/EU of the European Parliament and of the Council of 23 July 2016 establishing a framework for maritime spatial planning [2014] OJ L 257/135

\section{Swedish Law Sources}

Planning and Building Act (2010:900)

Local Government Act (1991:90o)

\section{Bibliography}

\section{Books}

Aarnio A, On coherence theory of law (Lund:Juristförl.: Akademibokh. distributör 1998). De Sousa Santos B, Law: A Map of Misreading - Toward a Postmodern Conception of Law (1987).

Delaney D, The spatial, the legal and the pragmatics of world-making: nomospheric investigations (Routledge 2010).

Lefebvre H, The production of space (Oxford: Basil Blackwell 1991).

Massey DB, For space (London: SAGE 2005).

Michanek G, EUs: adaptiva vattenplanering och svenska miljörättsliga traditioner (2016).

Osofsky H, Scales of law: Rethinking climate change governance (ProQuest Dissertations Publishing 2013).

Tuori K, Ratio and voluntas: the tension between reason and will in law (Ashgate 2011).

Valverde M, Jurisdiction and Scale: Legal 'Technicalities' as Resources for Theory (2009).

\section{Official Publications}

Committee of the Regions NAT-V-030, Opinion on proposed directive for maritime spatial planning and integrated coastal management (2013).

Common Implementation Strategy for the Water Framework Directive (2000/6o/EC) Guidance Document No 2. 
Common Implementation Strategy for the Water Framework Directive (2000/6o/EC) Guidance Document No 5 .

European Commission, EU Marine Strategy. The story behind the strategy (2006).

European MSP Platform, <http://www.msp-platform.eu/> accessed 2017-04-11.

European MSP Platform, 'Maritime Spatial Planning Information, Germany' (2016) $<$ http://www.msp-platform.eu/countries/germany> accessed 2017-03-22.

European MsP Platform, 'Maritime Spatial Planning Information, Lithuania' (2016) <http://www.msp-platform.eu/countries/lithuania > accessed 2017-03-22.

Rice J and others, 'ICES. Guidance in the Application of the Ecosystem Approach to Management of Human Activities in the European Marine Environment, ICES Cooperative Research Report, No. 273. 22'.

UNEP/CBD/COP/5/23, Decision V/6 Ecosystem Approach, (2000).

\section{Book Chapters}

Benda-Beckmann Fv and Benda-Beckmann Kv, 'Places That Come and Go: A Legal Anthropological Perspective on the Temporalities of Space in Plural Legal Orders' in Braverman I and others (eds), The expanding spaces of law: a timely legal geography (Stanford, California: Stanford Law Books 2014).

Braverman I and others, 'Expanding the Spaces of Law' in Braverman I and others (eds), The expanding spaces of law: a timely legal geography (Stanford, California: Stanford Law Books 2014).

De Santo E, 'The Marine Strategy Framework Directive as a Catalyst for Maritime Spatial Planning: Internal Dimensions and Institutional Tensions' in Gilek $\mathrm{M}$ and Kern K (eds), Governing Europe's marine environment: Europeanization of regional seas or regionalization of EU policies? (Farnham, Surrey: Ashgate 2015).

Smith N, 'Geography, Difference and Politics of Scale' in Doherty J, Graham E and Malek M (eds), Postmodernism and the social sciences (Basingstoke: Macmillan 1992).

Valverde M, “Time Thickens, Takes on Flesh”: Spatiotemporal Dynamics in Law' in Braverman I and others (eds), The expanding spaces of law: a timely legal geography (Stanford, California: Stanford Law Books 2014).

\section{Journal Articles}

Borja Á and others, 'Marine management - Towards an integrated implementation of the European Marine Strategy Framework and the Water Framework Directives' 60 Marine Pollution Bulletin 2175.

Christiernsson A, 'God miljöstatus och fiske - Hur effektiva är miljökvalitetsnormer?’ 2015:2 Nordic Environmental Law Journal 93.

Ford RT, 'Law's Territory (A History of Jurisdiction)' 97.4 Michigan Law Review 843. 
Hering D and others, 'The European Water Framework Directive at the age of 10: A critical review of the achievements with recommendations for the future' 408 Science of the Total Environment 4007.

Jans JH and others, “ “Gold plating” of European Environmental Measures?' 6 Journal for European Environmental \& Planning Law 417.

Jay S and others, 'Transboundary dimensions of marine spatial planning: Fostering inter-jurisdictional relations and governance' 65 Marine Policy 85 .

Lee KN, 'Greed, Scale Mismatch, and Learning' 3 Ecological Applications 560.

Long R, 'The Marine Strategy Framework Directive: A New European Approach to the Regulation of the Marine Environment, Marine Natural Resources and Marine Ecological Services' 29 Journal of Energy \& Natural Resources Law 1.

Moss B, 'The Water Framework Directive: Total environment or political compromise?' 400 Science of The Total Environment 32.

Sayre N, 'Ecological and geographical scale: parallels and potential for integration' 29 Progress in human geography 276.

van Leeuwen J and others, 'Implementing the Marine Strategy Framework Directive: A policy perspective on regulatory, institutional and stakeholder impediments to effective implementation' 50 Marine Policy 325.

van Tatenhove JPM, 'How to turn the tide: Developing legitimate marine governance arrangements at the level of the regional seas' 71 Ocean and Coastal Management 296.

Zervaki A, 'The legalization of maritime spatial planning in the European Union and its implications for maritime governance' 30 Ocean Yearbook 52. 